\title{
Skills that improve profitability: The relationship between project management, IT skills, and small to medium enterprise profitability
}

\author{
Julien Pollack (corresponding author), University of Technology Sydney \\ Daniel Adler, University of Technology Sydney \\ PO Box 123, Broadway, NSW, 2007, Australia
}

\begin{abstract}
It is a commonly assumed that using project management and IT skills are good for business performance. This research explored this assumption by testing whether the use of project management and IT skills have a positive affect on business' total sales and profitability. The research data was drawn from two longitudinal Government surveys of small to medium enterprises in Australia. Models were created to describe the relationship between project management, IT skills, profitability and total sales using multiple linear regression and binary logistic regression. The results show that when controlling for the influence of other business skills, project management and IT skills have a significant positive influence on sales and profitability.
\end{abstract}

Keywords: Project Management, Information Technology, Small to Medium Enterprise, Profitability, Sales, Business Skills 
Cite as: Pollack, J., Adler, D. (2016) Skills that improve profitability: The relationship between project management, IT skills, and small to medium enterprise profitability. International Journal of Project Management. 34, p. 831-838, http://dx.doi.org/10.1016/j.ijproman.2016.03.004

\section{Introduction}

It is a basic and fundamental assumption that developing business skills in your employees improves the profitability of your business. Although it may be difficult to test each step in the long and diffuse causal chain from an improved employee skill set to a better bottom line, the link between developing employee capability and improved company performance is typically taken as so obvious that it is rarely questioned. This assumption is held for skills such as the ability to manage projects, where it is taken for granted that using project management to reach strategic and operational objectives improves performance. Similarly, we tend to assume that increased information technology (IT) staff capability helps businesses not only survive, but excel in our currently changing technological climate. Were these assumptions false, there would be little justification to support the significant investments that organisations and individuals make on personnel development in these disciplines.

Many researchers have commented that project management improves the likelihood of an organisation being successful. The benefits of project management to organisations have been expressed as an improvement in productivity (McHugh \& Hogan, 2011; Cleland, 1984), effectiveness (Shenhar, Dvir, Levy, \& Maltz, 2001), efficiency (Stimpson, 2008), and performance (Abbasi \& Al-Mharmah, 2000), while the benefits of IT investment are commonly cited as providing strategic value (Carr, 2003), improved productivity (Hwang et al, 2015), and improved levels of organisational internal entrepreneurship (Benitez-Amando et al., 2010). This body of research appears to provide strong justification for sustaining the assumption that project management and IT skills support financial performance. 
Cite as: Pollack, J., Adler, D. (2016) Skills that improve profitability: The relationship between project management, IT skills, and small to medium enterprise profitability. International Journal of Project Management. 34, p. 831-838, http://dx.doi.org/10.1016/j.ijproman.2016.03.004

However, this assumption remains largely unexamined. In the project management literature, the debate more commonly focuses on developing idealised, or contingent, models of project management, ways of implementing these, and the examination of criteria that contribute to the success and failure of projects. In this regard, the IT literature is not that different, with an added emphasis on the impacts and opportunities associated with specific technological developments. In 2012, Hällgren (2012) called for an increased emphasis on research that explores the basic assumptions that underpin project management research and practice, and this research responds to that call by questioning whether the use of project management and IT as core business skills have an impact on businesses' financial performance, focusing on the roles these skills play in Australian small to medium enterprises (SME).

\section{Literature Review}

There is a large body of research that examines the ways in which project management can be improved, developed and refined, so that organisational objectives are delivered more effectively (e.g. Hagen \& Park, 2013; Kloppenborg et al., 2014). For instance, there have been a variety of studies that have linked personality types to project success (Creasy \& Anantatmula, 2013; Cohen et al., 2013), or factors that impact productivity on projects ( $\mathrm{Ng}$ et al., 2004). Other research has focused on process related issues, such as the link between project management process maturity and project success (Mir \& Pinnington, 2014), or links between the maturity of the portfolio management system in an organisation and project success (Reyck et al., 2005). One consistent emphasis in these studies is that they focus on project success rather than organisational performance. The relationship between project and business success is usually left to implication only. 
Cite as: Pollack, J., Adler, D. (2016) Skills that improve profitability: The relationship between project management, IT skills, and small to medium enterprise profitability. International Journal of Project Management. 34, p. 831-838, http://dx.doi.org/10.1016/j.ijproman.2016.03.004

Research that connects project management and organisational success is less common, but examples can be found in the literature. For instance, Ozcelik (2010) reported on ways that organisational performance was impacted by one particular type of project. Lappe and Sprang (2014) also investigated the impact of project management on the organisation, examining 251 projects that were managed by one German life insurance company. Their research involved the development of a model describing the relationship between the company's investment in project management and their return on investment, and showed a reliable relationship between project management costs and benefits. Another comparable study was conducted by Thomas and Mullay (2008), who also examined the return on investment from spending on project management. This research involved 65 participant organisations, and was able to demonstrate that in over half of the organisations there was a measurable value from their use of project management. However, the research findings were limited by few of the participant companies collecting the necessary data on their investment in project management processes.

It is more common for research to examine the relationship between IT and organisational performance. However, this “...literature has traditionally shown contradictory results regarding the impact of the IT artefact on firm performance" (Benitez-Amando et al., 2010, p. 551). Taking e-commerce as an example, Hau et al. (2015) found that e-commerce affected the gross operating profit for some categories of hotel, while a cross-sector study by Hwang et al (2015) found no link between e-commerce and business performance. Other studies have taken an indirect approach, often based on the assumption that IT is an enabler of business functions but not necessarily one that directly impacts upon performance. For example, IT capability has been found to indirectly affect business performance through customer orientation (Nakata et al., 2008). Investment in IT has also been found to positively affect a company's internal 
Cite as: Pollack, J., Adler, D. (2016) Skills that improve profitability: The relationship between project management, IT skills, and small to medium enterprise profitability. International Journal of Project Management. 34, p. 831-838, http://dx.doi.org/10.1016/j.ijproman.2016.03.004

entrepreneurship culture, which then indirectly affects company performance (Benitez-Amando et al., 2010), and to enable a proactive environmental strategy, which can in turn mediate the effect of IT on business performance (Benitez-Amando \& Walczuch, 2012).

Other studies (e.g. Lee et al., 2010) have uncovered a direct relationship between IT supported processes and organisational performance. However, the link between IT investment and performance does not appear to be universal. Hwang et al (2015) found that specific newer technologies positively impact upon productivity, but older aspects of IT, such as basic computer use and internet access were not found to improve productivity. This can be interpreted in light of Carr's (2003) research that suggests that as IT becomes ubiquitous, its strategic value diminishes. A common factor in these studies of the impact of IT investment is that they focus on IT artefacts and IT supported process. With the exception of Benitez-Amando et al (2010), these studies focus on the technology, not the embodied capability, leaving the impact of the use of IT as a core business skill on financial performance predominantly unexamined.

In addition to a lack of research that tests the assumption that there is a link between project management skills or IT skills, and financial performance, there is a tendency in the project management literature to focus on mega-projects (e.g. Turner, \& Müller, 2012; Flyvbjerg, 2014; Eweje et al., 2013; Winch, 2013; Brady \& Davies, 2014). In contrast to this prevailing trend, the research presented in this paper focuses on the impact of business skills on small to medium enterprise (SME) performance. The tendency to focus on larger projects is understandable, given how entertaining it is to read of their spectacular failures and successes, and the air of glamour associated with the large sums invested in mega-projects. However, the importance of SMEs to the social and economic health of countries has long been recognised (Beck et al., 
Cite as: Pollack, J., Adler, D. (2016) Skills that improve profitability: The relationship between project management, IT skills, and small to medium enterprise profitability. International Journal of Project Management. 34, p. 831-838, http://dx.doi.org/10.1016/j.ijproman.2016.03.004

2005; Schiffer \& Weder, 2001; Ayyagari et al., 2007). It is acknowledged that SMEs may, and do, contribute to larger projects, but SMEs more commonly work on smaller projects. SMEs account for $40-70 \%$ of the value added by the business sector, and $70-90 \%$ of all enterprises in OECD countries are SMEs (OECD, 2013a, 2013b). This is consistent with data from Australia; the context in which this research is set. In Australia, there were over one million SMEs operating in 2012, representing over $90 \%$ of the business sector (ABS, 2012a, 2012c) making SME profitability critical to the broader economy. In these SMEs, the Australian Bureau of Statistics (ABS) found IT professional skills in use in one in six SMEs, and project management used by one in eight SMEs (ABS, 2013a).

Project management research has often been submerged in the general management research into human resources, sales and marketing (Hudson et al, 2001; Turner et al, 2009; Turner et al, 2010). However, given that project management is a vital skill for SMEs (Turner et al., 2012), the critical role that project management plays in small business success (Sádaba et al, 2014), and the frequency with which IT professional skills and project management skills are used in SMEs, there is surprisingly little research which examines how these skills are used by SMEs, and how they affect business profitability.

\section{Methodology}

Data for this research was sourced from the ABS Business Longitudinal Database (BLD). The BLD includes data relevant to understanding the performance of Australian businesses. It is compiled from a number of sources, including Australian Government tax records and questionnaire responses. The ABS uses a data quality framework based on the Statistics 
Cite as: Pollack, J., Adler, D. (2016) Skills that improve profitability: The relationship between project management, IT skills, and small to medium enterprise profitability. International Journal of Project Management. 34, p. 831-838, http://dx.doi.org/10.1016/j.ijproman.2016.03.004

Canada Quality Assurance Framework (Statistics Canada, 2002) and the European Statistics Code of Practice (Eurostat, 2011). In the case of the survey data used in this research, a quality declaration was issued indicating a response rate of over $95 \%$, and a relative sampling error of less than $10 \%$.

In the 2004-05 financial year, the ABS selected a panel of SMEs based on them being representative of their industry or population group. Business details were sourced from the Australian Business Register (ABR), a database that contains the names and addresses of all businesses that have a registered Australian Business Number (ABN) with the Australian Taxation Office (ATO). Panel members were asked to respond to a survey for five consecutive years. The surveys were addressed to the owner / manager of the business, as listed in the $A B R$, asking them to complete and return the survey. Panel size was determined based on the expected drop out rate, and designed to ensure that a sufficiently large number of businesses remained in each industry sector and size classification for statistical analysis at the end of the five year period. New members were not introduced to the panel after the first year.

This research makes reference to two panels. Panel 1 includes data from the 2004-05 financial year to 2009-10, and Panel 2 includes data from the 2006-07 to the 2010-11 financial year. The BLD uses a variety of selection criteria for panel inclusion, including the requirements that businesses have less than 200 employees, that the business has a simple structure, and has only a single ABN (ABS, 2013b). The Oslo Manual survey development guidelines for measuring business innovation (OECD/Eurostat, 2005) were referenced in the development of the survey, and the BLD integrates with limited data from the ATO. These panels are of interest because they included questions regarding the core business skills that respondents used in conducting their business (ABS, 2012b, 2012c). The selection of skills included as options in the 
Cite as: Pollack, J., Adler, D. (2016) Skills that improve profitability: The relationship between project management, IT skills, and small to medium enterprise profitability. International Journal of Project Management. 34, p. 831-838, http://dx.doi.org/10.1016/j.ijproman.2016.03.004

survey are listed in the following section. These skills were selected to meet internal

Government policy concern about the Government's ability to meet skill shortages in science, engineering and technology related occupations. Interested readers should refer to Shah and Burke (2003) for discussion of relevant policy imperatives at that time.

Given the constraints of the data, this research has used the definition of an SME to be a trading business with less than 200 employees. BLD data has also been used in a variety of other research (ABS, 2014). This includes research into entrepreneurship behaviours (Fitzsimmons \& Douglas, 2006), outsourcing (Bakhtiari, 2013), performance (Steffens et al., 2009), productivity (Pollack \& Adler, 2014), industrial relations (Farmakis-Gamboni \& Prentice, 2001), family business operations (Dharmadasa, 2009), and innovation (Gronum et al., 2012; Bhattacharya \& Bloch, 2004; Huang \& Rice, 2009).

\section{Data Analysis}

The data analysis presented in this paper focuses on three questions, which have been paraphrased to account for the differences in the ways the questions were written in the survey instruments:

1. During the previous year, were any of the following types of skills used by the business in undertaking its core activities: engineering (ENG); scientific and research (SCI); IT professionals (ITP); IT support technicians (ITS); trades (TRA); transport; plant and machinery operation (MAC); marketing (MAR); project management (PM); business management (BUS); financial (FIN). 
Cite as: Pollack, J., Adler, D. (2016) Skills that improve profitability: The relationship between project management, IT skills, and small to medium enterprise profitability. International Journal of Project Management. 34, p. 831-838, http://dx.doi.org/10.1016/j.ijproman.2016.03.004

2. Total sales, as reported in Australian Tax Office Business Activity Statements.

3. Compared with the previous year, did profitability decrease, stay the same, or increase?

The relationship between profitability and Project Management

The first step in the analysis involved review of any possible correlation between whether respondents reported an increase in their profitability compared to the previous year, use of project management in their businesses, and their sales figures. Correlations $(p<0.01)$ were found in both Panels 1 and 2 between use of project management and change in profitability, and use of project management and total sales. The data are represented in Table 1 and Figure 1.

Figure 1: The relationship between project management (PM) and profitability

In Figure 1 it can be seen that more than $10 \%$ more of the populations of both Panels who used project management also reported an increase in their profitability, when this is compared to respondents who did not use project management. Furthermore, in both Panels, there were more than $5 \%$ less of the population who used project management to undertake their core business also reported decreasing profitability, compared to small business owners who did not use project management. A similar result can be seen in Table 1. SMEs that used project management reported an average of three times more sales than the SMEs that did not use project management to undertake their core business activities.

Table 1: The relationship between project management (PM) and sales 
Cite as: Pollack, J., Adler, D. (2016) Skills that improve profitability: The relationship between project management, IT skills, and small to medium enterprise profitability. International Journal of Project Management. 34, p. 831-838, http://dx.doi.org/10.1016/j.ijproman.2016.03.004

Interpretation of the Table 1 results should consider the unusually high maximum sales value for businesses that used project management in Panel 1, and the significant difference in standard deviations between these panels. Although it is not possible to tell from the data, it is likely that this company qualified for inclusion in Panel 1 at the start of the survey, and enjoyed disproportionate growth over the survey period. Once included in a panel, respondents were not removed from the population for future years. Removing this outlier from the data set brings the mean for Panel 1 businesses that used PM to $\$ 11,059,007$. This figure is comparable to the Panel 2 mean, and suggests that, excluding this outlier, there is reasonable consistency between the panels. This outlier was included in the subsequent analysis.

Although the differences between the means for companies that used and didn't use project management are promising results, they are not sufficient by themselves to demonstrate that using project management results in increased profitability and sales. To develop a clearer understanding of the influence of project management on these other variables, it was considered necessary to model the relationship when controlling for other variables.

\section{Modelling the Data}

Models were created to describe the relationship between SME profitability and businesses' use of a selection of skills, including project management and IT skills. The models were created using binary logistic regression, and backwards elimination was used to remove insignificant independent variables from the model. Logistic regression has been identified as "...the most important model for categorical response data..." (Agresti, 2013, p. 163). This type of model 
Cite as: Pollack, J., Adler, D. (2016) Skills that improve profitability: The relationship between project management, IT skills, and small to medium enterprise profitability. International Journal of Project Management. 34, p. 831-838, http://dx.doi.org/10.1016/j.ijproman.2016.03.004

“...is especially useful in epidemiological and demographic research in the assessment of the effects of explanatory factors on the relative risk of outcomes..." (Powers \& Xie, 2000, p. 49). These models describe the tendency of survey respondents to identify that their profitability had increased from the previous year, as opposed to staying the same, based on the influence of a specific set of business skills that the respondents may have used in undertaking their core business. Null hypotheses were developed to understand whether the models were useful, and to understand the contribution that project management and IT skills make to profitability. Although equivalent null hypotheses were created for the other business skills, they are not listed below for the sake of brevity. The relevant null hypotheses were:

- Null hypothesis - model: None of the coefficients in the model is significantly different from zero

- Null hypothesis - PM Skills: Project management skills have no significant effect on whether an organization reported an increase in profitability

- Null hypothesis - IT Professional Skills: IT professional skills have no significant effect on whether an organization reported an increase in profitability

- Null hypothesis - IT Support Skills: IT support technician skills have no significant effect on whether an organization reported an increase in profitability

The Panel 1 model was:

Logit $($ increase $)=(0.421$ * ITP $)+(0.222$ * ITS $)+(0.342$ * MAR $)+(0.313$ *PM $)+(0.310$ * FIN) -0.362

The Panel 2 model was:

$$
\text { Logit }(\text { increase })=(0.885 \text { * ENG })+(0.442 * \text { ITP })+(0.665 * M A R)+(0.562 \text { * PM })-0.245
$$


Cite as: Pollack, J., Adler, D. (2016) Skills that improve profitability: The relationship between project management, IT skills, and small to medium enterprise profitability. International Journal of Project Management. 34, p. 831-838, http://dx.doi.org/10.1016/j.ijproman.2016.03.004

Based on the Omnibus Tests of Model Coefficients, the significance of both models was 0.000 .

The null hypotheses for both models can therefore be rejected, and the models can be considered useful. The Panel 1 model accounts for $56.6 \%$ of dependent variable variation, while the Panel 2 model accounts for $58.4 \%$, with both models significant at 0.00 . The null hypotheses related to the significance of project management skills, IT professional skills, and marketing skills were rejected for both models. The null hypotheses related to the significance of IT support technician skills, engineering skills, and financial skills, could only be rejected in one model, giving inconclusive results. Null hypotheses related to the significance of scientific and research skills, trades skills, transport, plant and machinery skills, and business management skills were accepted for both models.

Table 2: The odds and probability of increased profitability

Using multiple linear regression it was possible to create models of the relationship between the use of business skills and SME total sales as reported in their tax documentation, with reference to (Weisberg, 2014). As with the previous model, backwards elimination was used to remove insignificant independent variables. The models represent the relative influence that each of the business skills have on the SME's total sales.

The Panel 1 model was:

$$
\begin{aligned}
& \text { Total sales }=1564973.48-(3369846.7 * \mathrm{SCI})+(4925023.22 * \text { ITP })+(3261601.44 \text { * ITS })+ \\
& (5392653.40 * \mathrm{PM})+\left(1940673.62{ }^{*} \mathrm{BUS}\right)+\left(2505495.36{ }^{*} \mathrm{FIN}\right)
\end{aligned}
$$

The Panel 2 model was: 
Cite as: Pollack, J., Adler, D. (2016) Skills that improve profitability: The relationship between project management, IT skills, and small to medium enterprise profitability. International Journal of Project Management. 34, p. 831-838, http://dx.doi.org/10.1016/j.ijproman.2016.03.004

Total sales $=1318112.44-(3082042.8 * \mathrm{SCl})+(3731526.44 *$ ITP $)+(2152968.39 *$ ITS $)+$ $(1295676.84$ * MAC $)+(4574069.42 * \mathrm{PM})+(1187796.93 *$ BUS $)+\left(2153946.41{ }^{*} \mathrm{FIN}\right)$

Both models were significant at 0.000 , and colinearity issues were not detected between the variables. The Panel 1 model explained $2.9 \%$ of the data $\left(R^{2}=0.029\right)$, while the Panel 2 model explained $7.1 \%$ of the data $\left(R^{2}=0.071\right)$. In both panels, the null hypotheses concerning the usefulness of the models, and the significance of project management skills, IT professional skills, IT support technician skills, business management skills, financial skills, and scientific and research skills were rejected. The results were inconclusive with respect to transport, plant and machinery skills, with the null hypothesis related to this skill set accepted for Panel 1, but rejected for Panel 2. Null hypotheses concerning the significance of trades and marketing skills to total sales were accepted for both panels.

\section{Discussion}

The first model presented above shows that using project management skills, IT professional skills, and marketing skills all increase the odds that respondents reported that their profitability had increased, as opposed to staying the same as the previous year. The results from the binary logistic regression models suggest that SMEs that invest in these skills may increase the likelihood that they will profitable. However, the role that subjective interpretation plays in respondents' answers should also be taken into account, in that the accuracy of respondents' answers was dependant upon their ability to correctly perceive changing profitability. Responses to this question may have been subject to some degree of error. 
Cite as: Pollack, J., Adler, D. (2016) Skills that improve profitability: The relationship between project management, IT skills, and small to medium enterprise profitability. International Journal of Project Management. 34, p. 831-838, http://dx.doi.org/10.1016/j.ijproman.2016.03.004

To mitigate the subjectivity of the first question set, this research has provided some degree of triangulation by modelling the relationship between respondents' total sales as reported in their Government tax documentation, and their use of different business skills. This modelling was done on the assumption that there is likely to be a relationship between a SMEs total sales and their profitability. However, it is acknowledged that the impact of changes in the cost of sales has not been accounted for in this analysis.

It was found that project management skills, IT professional and support skills, financial skills and business management skills had a significant positive relationship with the SME's total reported sales in both Panels. Of the business skills tested in the BLD, project management skills were shown to have the strongest positive correlation to total sales. The results for transport, plant and machinery operation skills were inconclusive, as they only significantly affected sales results in one panel. Marketing and trades skills were not found to have a significant influence on sales results, the former of which is particularly noteworthy given it's general disciplinary focus. It is also interesting to note that while scientific and research skills did show an influence on total sales in both panels, it was a negative. A possible explanation for this result can be attributed to the high-risks often associated with research and development. An alternative explanation is that research and development return on investment may only become apparent over a longer time scale than this survey has captured. Profitable research and development may be more viable in larger organisations than those that participated in the BLD, as larger organisations are more likely to be able to support the overheads associated with specialist scientific equipment, and have the contingency to survive the inevitable costs of failure associated with discovery.

\section{Limitations and future research}


Cite as: Pollack, J., Adler, D. (2016) Skills that improve profitability: The relationship between project management, IT skills, and small to medium enterprise profitability. International Journal of Project Management. 34, p. 831-838, http://dx.doi.org/10.1016/j.ijproman.2016.03.004

The intention of this research is to explore whether a reliable relationship exists between a selection of skills that SMEs sometimes use in undertaking their core business, their profitability, and their sales figures. It is important to note that the research purpose has not been to develop predictive models that include all factors influencing the dependant variable. This distinction is important, and the authors acknowledge that many variables influencing SME profitability and sales have not been considered in this research. The skills that individuals bring to a business will certainly affect how profitable it is, and it is arguable that the skills of any one individual will be proportionally more influential in a SME than a large corporation, but business skills by no means exclusively determine business profitability and sales. This research makes no comment about other factors that may be relevant, such as the maturity of the business, the competitive environment, government policies, the prevailing business climate, or organisational culture.

Given that the research purpose was to investigate the possibility of a reliable relationship between profitability and the use of different business skills, and also given the dataset size, the model $R^{2}$ values should be considered as adequate. Readers are referred to comparable $R^{2}$ values in other research (Karabag \& Berggren, 2014; Hu \& Hibel, 2014; Fullerton \& Wallace, 2007; Monge-Rojas et al, 2002). Knofczynski \& Mundfroms' (2008) research recommends appropriate sample sizes for multiple regression for models created to predict the dependant variable behaviour, and it is noted that the sample sizes that have been used in this research are significantly greater than were considered in Knofczynski \& Mundfroms' analysis. In addition, Maxwell (2000, p. 435) has noted that “...sample size will almost certainly have to be much larger for obtaining a useful prediction equation than for testing the statistical significance of the multiple correlation coefficient". This suggests that the models presented here may be valid predictive models, but given that the purpose of this research has not been to develop 
Cite as: Pollack, J., Adler, D. (2016) Skills that improve profitability: The relationship between project management, IT skills, and small to medium enterprise profitability. International Journal of Project Management. 34, p. 831-838, http://dx.doi.org/10.1016/j.ijproman.2016.03.004

predictive models, some caution should be exercised if the models are to be used in this way. These models show that there is a reliable relationship between the dependant variable and selected independent variables, and future research may consider the possibility of expanding the pool of independent variables tested, with purpose of developing models that more accurately predict the dependent variables' behaviour.

Three other limitations to this research should also be observed. Firstly, the responses to the question about changing profitability will have been affected by the ability of respondents to accurately perceive this change. However, this possible source of error will at least have partly been ameliorated by the creation of the second set of models that described changes in sales figures. Second, the Panels also exclusively focus on businesses with less than 200 employees in Australia. This should be considered when extending these research findings to businesses in other countries, or to larger organisations. Third, it is expected that there will have been variation in how the respondents understood what it is to use these business skills, as the survey instrument did not provide definitions. One respondent may have considered that creating a simple time line on a spread sheet counts as using project management, while another may have thought project management to be practiced only by those with a higher degree. Similar variation may have occurred in how respondents interpreted IT skills, what it means for these skills to have been used 'by the business', and variation in the degree to which these skills played a role in the businesses. However, it is likely that there has been some convergence towards a common understanding of these business skills given the sample size. Other areas for future research could involve exploration of the boundary between when different business skills are considered to be used in a SME's core business, how this may vary in larger organisations, and factors that affect how changes in profitability are perceived. 
Cite as: Pollack, J., Adler, D. (2016) Skills that improve profitability: The relationship between project management, IT skills, and small to medium enterprise profitability. International Journal of Project Management. 34, p. 831-838, http://dx.doi.org/10.1016/j.ijproman.2016.03.004

\section{Conclusion}

In response to Hällgren's (2012) call for an increased emphasis on research that explores the basic assumptions that underpin project management research and practice, this paper has explored whether project management and IT skills improve business results. The research was conducted using two longitudinal databases, and it was found that the surveyed businesses that used project management more commonly reported an increase in profitability, and less commonly reported a decrease in profitability. At least $10 \%$ more of the population that used project management reported increasing profitability, and $5 \%$ less of the population reported a decrease in profitability, compared to those who didn't use project management. Furthermore, businesses that used project management reported sales figures that were on average three times higher than those that did not.

The hypotheses that project management and IT professional skills have a significant positive relationship with SME profitability were tested using binomial logistic regression. When controlling for the influence of other comparable business skills, project management and IT professional skills were found to have a significant positive influence on the likelihood of a SME reporting an increase in profitability. The hypotheses that project management and IT professional skills have a significant impact on SME total sales were tested using multiple linear regression. When controlling for the influence of other business skills, it was found that project management and IT professional skills have a significant positive relationship with total sales.

The findings presented in this paper provide an additional perspective to earlier research that investigated the links between project management skills, IT skills, and business performance. Research by Lappe and Sprang (2014) and Thomas and Mullay (2008), showing that 
Cite as: Pollack, J., Adler, D. (2016) Skills that improve profitability: The relationship between project management, IT skills, and small to medium enterprise profitability. International Journal of Project Management. 34, p. 831-838, http://dx.doi.org/10.1016/j.ijproman.2016.03.004

companies receive a measurable value from investment in project management, used different research methods to those used in this paper. The results presented in this paper provide some triangulation of their findings. Less research has been conducted on the links between IT skills and business performance, with most research either showing contradictory results, or focusing on the impact of IT artefacts (Benitez-Amando et al., 2010, p. 551), rather than embodied capability. Research by Benitez-Amando and Walczuch (2012) has suggested that IT plays an indirect mediating effect on improving business performance, and this research develops on their findings.

The results presented in this paper indicate that using project management and IT professional skills to undertake core business activities make a significant contribution to improving the financial performance of small to medium enterprises. Companies often have to make difficult decisions about investment in resources. This particularly significant for small to medium enterprises, where both human and financial resources may be scarce. Strategic decisions about investment in personnel and their development can have a significant impact on company performance. When considering which skills it is worthwhile developing as organisational capabilities, this research has shown that investment in project management and IT professional skills may have the greatest impact on an organisation's performance.

\section{Acknowledgement}

This paper is based on research presented at the 2015 Global Conference on Business and Finance. The author wishes to thank the conference participants for their feedback, which has 
Cite as: Pollack, J., Adler, D. (2016) Skills that improve profitability: The relationship between project management, IT skills, and small to medium enterprise profitability. International Journal of Project Management. 34, p. 831-838, http://dx.doi.org/10.1016/j.ijproman.2016.03.004

contributed to the development of this paper. The authors also wish to thank the Centre for

Contemporary Design Practice for the grant that allowed this research to take place.

\section{REFERENCES}

- Abbasi, G., \& Al-Mharmah, H. (2000) "Project management practice by the public sector in a developing country," International Journal of Project Management, vol. 18, p. 105109.

- ABS. (2013a) "8167.0 - Selected Characteristics of Australian Business, 2011-12,"

Australian Bureau of Statistics, Retrieved from

http://www.abs.gov.au/ausstats/abs@.nsf/mf/8167.0

- ABS. (2013b) "About the Business Longitudinal Database," Australian Bureau of Statistics. Retrieved from

http://www.abs.gov.au/ausstats/abs@.nsf/Latestproducts/8168.0.55.001Main\%20Featur es42006-07\%20to\%202010-

11 ?opendocument\&tabname=Summary \&prodno=8168.0.55.001\&issue $=2006-$

07\%20to\%202010-11\&num=\&view=

- $\quad$ ABS. (2012c) "8168.0.55.001 - Microdata: Business Longitudinal Database, Australia, 2006-07 to 2010-11," Australian Bureau of Statistics, Retrieved from http://www.abs.gov.au/ausstats/abs@.nsf/mf/8168.0.55.001

- ABS. (2014) "Published Research - Business Longitudinal," Australian Bureau of Statistics, Retrieved from http://abs.gov.au/websitedbs/d3310114.nsf/4a256353001af3ed4b2562bb00121564/56b e6f3fa156877cca25728a000c18fc!OpenDocument

- Agresti, A. (2013) Categorical Data Analysis. Wiley, New Jersey. 
- Ayyagari, M., Beck, T., \& Demirguc-Kunt, A. (2007) "Small and medium enterprises across the globe," Small Business Economics, vol. 29, p. 415-434.

- Bakhtiari, S., \& Breunig, R. (2013) “Outsourcing and innovation: An empirical exploration of the dynamic relationship," B.E. Journal of Economic Analysis and Policy. April, p. 124.

- Beck, T., Demirguc-Kunt, A., \& Levine, R. (2005) "SMEs, growth, and poverty: Crosscountry evidence," Journal of Economic Growth, vol. 10, p. 199-229.

- Benitez-Amando, J., Llorens-Montes, F. \& Perez-Arostegui, M. (2010) “Information technology-enabled intrapreneurship culture and firm performance", Industrial Management \& Data Systems, vol. 110, no. 4, pp. 550-566.

- Benitez-Amando, J. \& Walczuch, R. (2012), "Information Technology, the organizational capability of proactive corporate environmental strategy and firm performance: a resource based analysis", European Journal of Information Systems, vol. 21, pp. 664679.

- Bhattacharya, M., \& Bloch, H. (2004) "Determinants of innovation," Small Business Economics, vol. 22, p. 155-62.

- Brady, T., \& Davies, A. (2014) "Managing structural and dynamic complexity: A tale of two projects," Project Management Journal, vol. 45(4), p. 21-38.

- Carr, N. (2003) "IT Doesn't Matter", Harvard Business Review, no. May, pp. 41-49.

- Chang, A., Chih, Y., Chew, E., \& Pisarski, A. (2013) "Reconceptualising mega project success in Australian defence: Recognising the importance of value co-creation," International Journal of Project Management, vol. 31(8), p. 1139-1153.

- Cleland, D. (1984) "Pyramiding project management productivity," Project Management Journal, p. 84-95. 
- Cohen, Y., Ornoy, H., \& Keren, B. (2013) “MBTI personality types of project managers and their success: A field survey," Project Management Journal, vol. 44(3), p. 78-87.

- Creasy, T., \& Anantatmula, V. (2013) "From every direction: How personality traits and dimensions of project managers can conceptually affect project success," Project Management Journal, vol. 44(6), p. 36-51.

- Dharmadasa, P. (2009) Organisational learning, innovation and performance in familycontrolled manufacturing small and medium-sized enterprises (SMEs) in Australia, Ph.D. Thesis. Bond University, Queensland.

- Eurostat (2011) European Statistics Code of Practice. Eurostat. Accessed online at http://ec.europa.eu/eurostat/web/products-manuals-and-guidelines/-/KS-32-11-955

- Eweje, J., Turner, R., \& Müller, R. (2012) "Maximising strategic value from megaprojects: The influence of information-feed on decision-making by the project manager," International Journal of Project Management, vol. 30(6), p. 639-651.

- Farmakis-Gamboni, S., \& Prentice, D. (2011) "When does reducing union bargaining power increase productivity? Evidence from the Workplace Relations Act," Economic Record, 87, 603-616.

- Fitzsimmons, J., \& Douglas, E. (2006) “Entrepreneurs and funding decisions: Evidence from Australian SMEs," Journal of Entrepreneurship and Small Business, vol. 3, p. 7691.

- Flyvbjerg, B. (2014) "What you should know about megaprojects and why: An overview," Project Management Journal, vol. 45(2), p. 6-19.

- Fullerton, A., \& Wallace, M. (2007) “Traversing the flexible turn: US workers' perceptions of job security, 1977-2002," Social Science Research, vol. 36, p. 201-221. 
- Gronum, S., Verreynne, M., \& Kastelle, T. (2012) "The role of networks in small and medium-sized enterprise innovation and firm performance," Journal of Small Business Management, vol. 50, p. 257-282.

- Hagen, M., \& Park, S. (2013) “Ambiguity acceptance as a function of project management: A new critical success factor," Project Management Journal, vol. 44(2), p. $52-66$.

- Hällgren, M. (2012) "The construction of research questions in project management," International Journal of Project Management, vol. 30, p. 804-816.

- Hau, N., Morosan, C. \& DeFranco, A. (2015) "The other side of technology adoption: Examining the relationships between e-commerce expenses and hotel performance," International Journal of Hospitality Management, vol 45, p. 109-120.

- Hu, A., \& Hibel, J. (2014) "Changes in college attainment and the economic returns to a college degree in urban China, 2003-2010: Implications for social equality," Social Science Research, vol. 44, p. 173-186.

- Huang, F., \& Rice, J. (2009) "The role of absorptive capacity in facilitating 'open innovation' outcomes: A study of Australian SMEs in the manufacturing sector," International Journal of Innovation Management, vol. 13, p. 201-220.

- Hudson, M., Smart, A., \& Bourne, M. (2001) "Theory and practice in SME performance measurement systems," International Journal of Operations \& Production Management, vol. 21 , p. $1096-1115$.

- Hwang, J., Kim, S. \& Lee, H. (2015) "Breaking the Myths of the IT Productivity Paradox", KSII Transactions on Internet and Information Systems, vol. 9, no. 1, pp. 466-482.

- Karabag, S., \& Berggren, C. (2014) "Antecedents of firm performance in emerging economies: Business groups, strategy, industry structure, and state support," Journal of Business Research, vol. 67, p. 2212-2223. 
- Kloppenborg, T., Tesch, D., \& Manolis, C. (2013) "Project success and executive sponsor behaviors: Empirical life cycle stage investigations," Project Management Journal, vol. 45(1), p. 9-20.

- Knofczynski, G., \& Mundfrom, D. (2008) “Sample Sizes When Using Multiple Linear Regression for Prediction," Educational and Psychological Measurement, vol. 68, p. 431442.

- Lappe, M., \& Sprang, K. (2014) "Investments in project management are profitable: A case study-based analysis of the relationship between the costs and benefits of project management," International Journal of Project Management, vol. 32, p. 603-612.

- Maxwell, S. (2000) "Sample size and multiple regression analysis," Psychological Methods, vol. 5, p. 434-458.

- Lee, C., Huang, S., Barnes, F. \& Kao, L. (2010) "Business performance and customer relationship management: The effect of IT, organisational contingency and business process on Taiwanese manufacturers", Total Quality Management, vol. 21, no. 1, pp. 4365.

- McHugh, O., \& Hogan, M. (2011) "Investigating the rationale for adopting an internationally-recognised project management methodology in Ireland: The view of the project manager," International Journal of Project Management, vol. 29, p. 637-646.

- Mir, F., \& Pinnington, A. (2014) "Exploring the value of project management: Linking project management performance and project success," International Journal of Project Management, vol. 32, p. 202-217.

- Monge-Rojas, R., Nunez, H., Garita, C., \& Chen-Mok, M. (2002) "Psychosocial Aspects of Costa Rican Adolescents' Eating and Physical Activity Patterns," Journal of Adolescent Health, vol. 31, p. 212-219.

- Nakata, C., Zhu, Z. \& Kraimer, M. (2008) "The Complex Contribution of Information 
Technology Capability to Business Performance", Journal of Managerial Issues, vol. 20, no. 4 , pp. $485-506$.

- Ng, A., Skitmore, R., Lam, K., \& Poon, A. (2004) "Demotivating factors influencing the productivity of civil engineering projects," International Journal of Project Management, vol. 22 , p. 139-146.

- OECD. (2013a) "Enterprises by size class," Entrepreneurship at a Glance 2013, The Organisation for Economic Co-operation and Development Publishing, Paris, France.

- OECD. (2013b) "Value added by size class," Entrepreneurship at a Glance 2013, The Organisation for Economic Co-operation and Development Publishing, Paris, France.

- OECD/Eurostat. (2005) Oslo Manual: Guidelines for Collecting and Interpreting Innovation Data, 3rd Edition, The Measurement of Scientific and Technological Activities, The Organisation for Economic Co-operation and Development Publishing, Paris, France.

- Ozcelik, Y. (2010) "Do business process reengineering projects payoff? Evidence from the United States," International Journal of Project Management, vol. 28, p. 7-13.

- Pollack, J., Adler, D. (2014) “Does Project Management Affect Business Productivity: Evidence From Australian Small to Medium Enterprises," Project Management Journal, vol. 45 , p. $17-24$.

- Powers, D. \& Xie, Y. (2000) Statistical Methods for Categorical Data Analysis. Academic Press, London.

- Reyck, B., Gurushka-Cockayne, Y., Lockett, M., Calderini, R., Moura, M., \& Sloper, A. (2005) "The impact of project portfolio management on information technology projects," International Journal of Project Management, vol. 23, p. 524-537. 
- Sádaba, S., Pérez-Ezcurdia, A., Lazcano, A., \& Villanueva, P. (2014) “Project risk management methodology for small firms," International Journal of Project Management, vol. 32, p. 327-340.

- Schiffer, M. \& Weder, B. (2001) Firm size and the business environment: Worldwide survey results, International Finance Corporation Discussion paper 43, World Bank, Washington, DC. Retrieved from wwwwds.worldbank.org/external/default/WDSContentServer/IW3P/IB/2001/12/01/000094946 _01111704003345/additional/585559324_200409289103425.pdf

- Shah, C. and Burke, G. (2003) Skill Shortages: concepts, measurement and implications, Centre for the Economics of Education and Training, Melbourne, Monash University.

- Shenhar, A., Dvir, D., Levy, O., \& Maltz, A. (2001) "Project success: A multidimensional strategic concept," Long Range Planning, vol. 34, p. 699-725.

- Statistics Canada (2002) Statistics Canada's Quality Assurance Framework, Statistica Canada, Ontario. Accessed online at http://unstats.un.org/unsd/industry/meetings/eg2008/AC158-11.PDF.

- Steffens, P., Davidsson, P., \& Fitzsimmons, J. (2009) "Performance configurations over time: Implications for growth- and profit-orientated strategies," Entrepreneurship Theory \& Practice, vol. 33, p. 125-148.

- Stimpson, J. (2008) "Project management: A means to efficiency," Practical Accountant, June, 17-21.

- Thomas, J., \& Mullaly, M. (2008) Researching the value of project management. Newtown Square, PA: Project Management Institute. 
- $\quad$ Turner, J.R., Ledwith, A., \& Kelly, J. (2009) "Project management in small to mediumsized enterprises: A comparison between firms by size and industry," International Journal of Managing Projects in Business, vol. 2, p. 282-296.

- Turner, R., Ledwith, A., \& Kelly, J. (2010) "Project management in small to mediumsized enterprises: Matching processes to the nature of the firm," International Journal of Project Management, vol. 28, p. 744-755.

- Turner, R., Ledwith, A., \& Kelly, J. (2012) "Project management in small to mediumsized enterprises: Tailoring the practices to the size of company," Management Decision, vol. 50, p. 942-957.

- Weisberg, S. (2014) Applied Linear Regression, $4^{\text {th }}$ Edition. Wiley, New Jersey.

- Winch, G. (2013) "Escalation in major projects: Lessons from the channel fixed link," International Journal of Project Management, vol. 31(5), p. 724-734. 